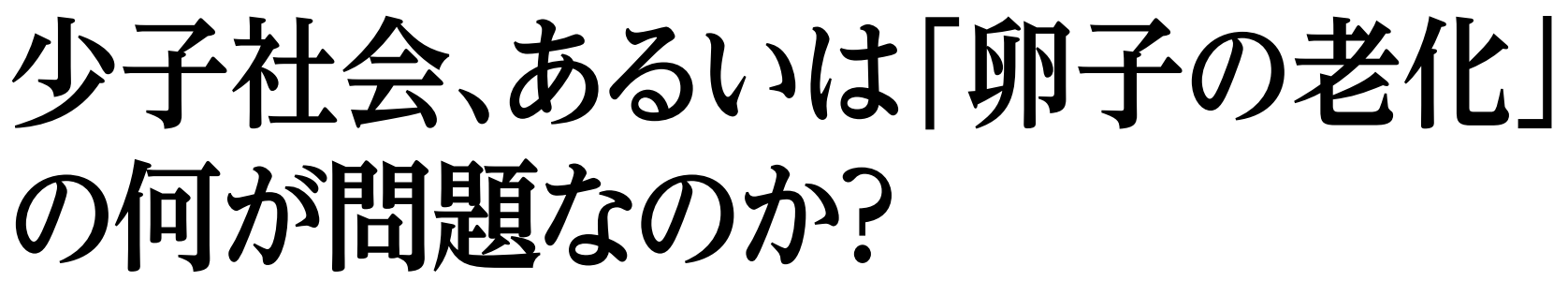

小浜正子

\section{はじめに一何が問題なのか ?}

今回の特集は、「『卵子の老化』が問題になる 社会を考える」ということだが、そもそも「卵 子の老化」の何が問題なのだろうか？

「卵子の老化」という言葉で象徵しようとし ていることは、端的には女性の加齢による妊孕 率の低下（および流産率の上昇）のために、子 供が産まれにくくなる、ことかと思われる。そ れは一体、誰にとって、どのように「問題」な のか。

回答には、二つの方向があるだろう。第一は、 社会全体（あるいは国）にとっての問題で、「卵 子の老化」のために、出生率が低下して、社会 の再生産が順調にいかなくなるような事態が起 こることである（ここに含まれる論理の飛躍に ついては、今は閣く)。第二は、子供を持ちた い個々の女性やカップルにとっての問題で、加 齢によって子供を産める可能性が少なくなるこ とである。

この二つは、関連はあるが、別の問題である。 だが、この両者は無意識に、あるいは意図的に 混同されて、出生率の低下を防ぐためにすべて の女性に若年での出産を奨励しているとも取れ る情報が、高校副教材に載せられていたという。 そのようなことは、リプロダクティブ・ライッ (生殖の自己決定権) からみて、大きな問題が
ある。しかしそもそも、子供を持ちたい個々の 女性やカップルにとっての問題とは、実際のと ころ、どこに存在しているのか。

\section{若いうちに産めない}

一お金も時間も足りない現状

2011年、女性の第一子出産年齢の平均は 30 歳を超えた（厚生労働省調査）。子供を持ちた い女性やカップルが、若いうちに産まない／産 めないのは、なぜなのか。

まず考えられる大きな理由は、経済的要因で ある。21世紀にはいってから日本の勤労者の 所得水準は低下し続けているが、とりわけ20 代〜30代の所得分布は、低所得層にシフトし ている1。所得の高さと結婚率とは相関関係が あるので、非嫡出子の割合が少ない日本では、 若年層の所得低下は、晚婚化、そして少子化に 直結している。

若い世代の所得低下はまた、一人の収入での 家計維持を困難にしている。ならば共働きをし て二人の収入で子供を育てょうと思っても、「保 育園落ちた日本死ね」が2016年の流行語大賞 に選ばれたように、社会的な育児支援は非常に 不充分で、保育園に入れるかどうかもわからな い。2017年度には行政の努力により若干の保 育園の定員増がはかられたが、待機児童がゼロ 
になるにはほど遠い。これでは、子供を持つこ と、とりわけ若いうちに産み育てることは困難 である。

このような状況を解決するには、子育て支援、 すなわち所得の少なさを補う「子ども手当」な どの現金給付や、低額で良質な保育を提供する 現物給付を充実させることが必要である。

また、日本の労働者の労働時間は非常に長 く、特に子育て世代の 30 代の男性の労働時間 は長くなっていて、育児参加が難しく、女性 に過大な負担がかかっている。6才未満の小さ な子供を持つ夫の家事・育児関連時間は、日本 では一日に 67 分と諸外国に比べて極端に低い。 子供がいて夫が休日に6 時間以上を家事・育児 に費やす夫婦の $76.5 \% に は$ 第二子が生まれてい るが、夫の家事・育児時間がゼロの場合には $14 \%$ であり、夫の家事・育児への参画程度と子 供の数には明白な相関がある ${ }^{2}$ 。長時間労働を 是正して、男女ともにワークライフ・バランス の取れた生活を送る、とりわけ男性が家事・育 児に参画できるようにすることが、子供を養育 する必須の条件であることがわかる。

\section{不妊への処方箋}

\section{一生殖補助医療か、養子・里子か}

子供を欲しくても不妊のカップルは、日本 では 5.5 組に 1 組ともいわれる。そうした場合、 不妊治療を行うことは一つの選択肢であり、少 子化社会への対策として公費による助成も行わ れている ${ }^{3}$ 。近年は、高度な不妊治療である体
PROFILE

小浜正子 (こはま まさこ)

曰日本学術会議連携会員

日日本大学文理学部教授

專門 中国ジェンダー史

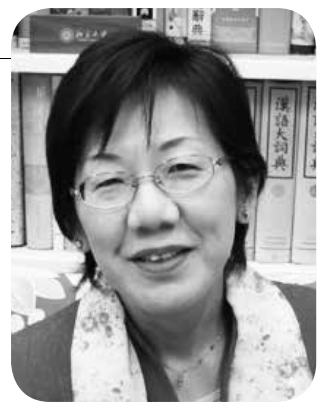

外受精などの生殖補助医療（ART）も普及し、 2014 年には年間 47,322 人、全出生児数の約 21 人に 1 人に上った ${ }^{4}$ 。とはいえ、不妊治療によっ て子供を持とうとしても、必ずしも希望が叶う わけではなく、とりわけ年齢を重ねると難しく なる現状は、本特集の他の論文が伝えるとおり である。

さらに、生殖補助医療（ART）には、精子 提供・卵子提供・代理母という不妊カップル以 外の他者の身体や遺伝子を介在させる方法も登 場している。それらによっても必ずしも子供が 得られるとは限らないだけでなく、そうした生 殖のあり方に対する社会的なコンセンサスや法 制度が、日本ではいまだ整っていないのが現状 である。

一方、不妊だが子供を欲しい場合の、別の選 択肢として養子を迎える方法がある。览童相談 所や関連 NPO法人などの斡旋により、子供を 里子として家庭で育てた後、法的な手続きを経 て養子となる。平成 25 年 2 月発表の厚生労働省 調查では、児童養護施設に入所している児童数 は約 3 万人で、そのうち、養子となるのは年に 300 ～ 400 人、里子となるのは 4,000 人程度で あり、多くの子供が里子・養子に迎えられてい るとはいえない。

養子が増えない理由に、斡旋団体等の定める 里親・養親の条件がかなり厳しいことがある。 条件は団体ごとに異なるが、お拈むね次のよう 
なものである。まず養親は法律婚をしている夫 婦に限られる。また、一定以上の所得が必要な だけでなく、年齢制限（おおむね 40 才くらい まで) があり、さらに夫婦の一方が専業主婦（主 夫）であるか、当初は育児に専念すること、な どが要求される。

養子を迎える家庭を審査することは、子供を しあわせに育てる環境を確保する上で必要なこ とである。ただどのような環境が子供を育てる のにふさわしいとするかは、社会によって異な る。日本で「子供を育てるに望ましい環境」と 想定されているのは、一定以上の収入のある夫 と専業主婦の妻の、法律婚をしている、年齢が 高すぎない夫婦であり、性別分業を念頭に置い た家族規範とそれを支える制度の枠組みの中の ものだといえる。

以上からは、若いときには簡単に産めず、不 妊治療は不確実でとりわけ高齢になると難し く、しかし里子・養子を迎えるのも容易でない、 という、子供を持とうと思っても困難の大きい、 ダブルバインド、トリプルバインドの日本の現 状がうかびあがってくる。

\section{家族規範と少子化}

不妊の夫婦には、近年、次のようなダブルバ インドも起きている。すなわち不妊治療をした が妊娠・出産に至らず、その後で養子を望んで も年齢制限を超えていてダメなケースが増加し ているというのである。二つの選択肢の中で、 不妊治療で実子を得ることを優先したが叶わ
ず、結果として養子を迎えることも叶わなかっ たケースである。本特集の白井論文によれば、 不妊カップルが卵子提供により子を得る可能性 がある時は、養子縁組より卵子提供が選択され る傾向があるといい、（夫の）遺伝的な子を得 ることに高い優先順位が置かれているようだ。

ここからは、日本において、生殖技術の進歩 は本当に選択肢を広げているのか、を考える必 要があるように思われる。以前は不可能だった ケースでも遺伝的な子を得る可能性のある技術 が出現したことが、それを求める家族規範をよ り重視する傾向を導いており、しかしそのこと によって子供をもてる可能性が本当に大きく なっているかは不明なのである。

国外では、生殖技術の進歩により、（適切な 技術の利用法かどうかは議論の余地もあるとは いえ）女性が卵子を凍結保存してキャリアを積 んだ後に子供を持つことをはかったり、同性 カップルが遺伝的つながりのある子供を得るこ とが可能になったりしている（同性カップルが 養子を迎えることも、ひろく行われている)。

しかし日本では、不妊治療を受けられるのは 法律婚の夫婦に限るという日本産科婦人科学会 の倫理基準もあって、技術の進歩が必ずしも子 供の持ち方の多様性を広げることに結びついて こなかった。

ここからは、落合恵美子のいう、ヨーロッパ では制度としての婚姻が弱体化して、家族は多 様な親密圈（事実婚カップル、同性カップル、 養子等を含む）へと変容しているのに対して、 日本では、制度としての結婚の形は保たれてい 
るが、そのような家族は細っていって、それに 代わる親密圈は欠如しているという状況が、想 起される ${ }^{5}$ 。リプロダクションの側面でも、制 度としての家族の「型」- 法律婚の男女の夫婦 とその実子による家族ーは保たれても、現実に はそうした家族を形成することの困難は大き く、結果として少子社会となっているのである。

\section{おわりに一開かれた、多様な「家族」へ}

以上より、明らかになったのは、次の様なこ とであった。子供を持ちたい女性やカップル が「高齢化」する前に子供を産める社会とする ためには、現金給付と現物給付の両方を含む子 育て支援の充実が必要である。また、とりわけ 子育て世代の男性に顕著な長時間労働を是正し て、男女ともにワークライフ・バランスのとれ た生活を送れるようにする必要がある。

同時に、不妊治療や養子縁組の際に求められ る条件や、またそれを利用しようとする側の家 族規範に関する態度にも、再考の余地があろう。

そもそも、出産の回数や時期、養子を含めた 子供の持ち方など、家族の形や次世代の養育の あり方は、歴史的に変化するものである。

日本社会の家族の「型」も、前述の日本産科 婦人科学会の倫理基準が 2015 年に修正され 6 、 2017 年には、はじめて大阪市でゲイ・カップ ルが里親として認定されるなど、変化のきざし も見える。

すでに、現実の教室には、法律婚をしている 夫婦の許で育てられる実子以外の多様な子供た
ちが存在している。ひとり親家庭や、事実婚カッ プルの子供、ステップファミリー、祖父母など とのみ暮らす子供、養子・里子、施設で暮らす 子供たち。さらに、将来、規範的家族をつくり はしないだろうLGBTの子供たち。ART出生 児。親が家族規範の異なる外国に出自をもつ子 供たち、また貧困家庭の子供たちもいる。しか しこうした従来の規範的家族の「型」にはまら ない子供たちは、教室で「見えにくい」存在に なっている。かれらの存在を当然のこととして 受け入れ、共存する社会をつくることが、「家族」 （あるいは親密圈）のあり方を多様なものに開 いてゆき、これから子供を持とうとする女性や カップルに、多様な方法で次世代を養育できる 可能性を高めることにつながると思われる。

注

1 「育て世代＝若年層の所得伸び悩み具合をグラフ化してみ る(2017年) (最新)」

http://www.garbagenews.net/archives/2021156.html

2 内閣府「平成 27 年度版少子化社会対策白書」より。 http://www8.cao.go.jp/shoushi/shoushika/whitepaper/ measures/w-2015/27webhonpen/html/b1_s1-1-4.html

3 少子化対策として不妊治療を推進することには、批判もあ る。白井千晶「日本における不妊をめぐる身体政治一不妊 治療費への健康保険適用と公費助成を例に」(小浜正子・松 岡悦子編『アジアの出産と家族計画一「産む・産まない． 産めない」身体をめぐる政治』勉誠出版、2014年）参照。

4 「NPO法人Fine 現在・過去・未来の不妊体験者を支援す る会」ホームページ参照。http://j-fine.jp/

5 「東アジアの低出生率と家族主義」落合編『親密圏と公共圏 の再編成一アジア近代からの問い』京都大学学術出版会、 2013。

6 同学会は、「社会情勢の変化により夫婦のあり方に多様性が 増した結果、医療現場ではいわゆる社会通念上の夫婦にお いても不妊治療を受ける権利を尊重しなければならないの も事実」であることに鑑みて、生殖補助医療の対象者を「婚 姻しており」とする表現を削除した。(「『体外受精・胚移植 ノヒト胚および卵子の凍結保存と移植に関する見解』にお ける『婚姻』の削除について」(平成26年6月発表) http://www.jsog.or.jp/ethic/rinri_kaikoku_201406.html 